Original research article

\title{
The lived experience of Indonesian nurses in Kuwait: A phenomenological study
}

\author{
Ferry Efendi ${ }^{1 *}$, Sylvia Dwi Wahyuni ${ }^{1}$, Retno Indarwati ${ }^{1}$, Setho Hadisuyatmana ${ }^{1}$, Anna Kurniati ${ }^{2}$, \\ Zulkifli Abdullah Usin ${ }^{3}$ \\ ${ }^{1}$ Universitas Airlangga, Faculty of Nursing, Surabaya, Indonesia \\ ${ }^{2}$ Ministry of Health, BPPSDMK, Center for Planning and Management of Human Resources for Health, Jakarta, Indonesia \\ ${ }^{3}$ Adan Hospital Kuwait, Hadiya, Kuwait
}

\begin{abstract}
Introduction: Indonesia is recognized as an active player in the sending of health professionals, including nurses, abroad. Indonesian nurses are also placed in Middle Eastern countries, such as Kuwait. Nevertheless, there is little research exploring the life experience of Indonesian nurses living and working in Kuwait.

Methods: The design of this study was qualitative with a phenomenological approach. Participants in this study were 21 Indonesian nurses who have lived and worked in Kuwait for a minimum of one year. The participants were recruited from hospitals in Kuwait. This study used a semi-structured interview which was conducted in appointed places. Data were then transcribed verbatim and thematically analyzed.

Results: Five themes were identified, namely: Escalating career prospects; Immersing in the local culture; Added value for Muslims; Language barriers; and Dealing with homesickness.

Discussion: Participants' economic and social motives reflected different migration goals. Meanwhile, living in a Muslim country lessens the stress and may serve as a benefit during migration.

Conclusions: Indonesian nurses who work in Kuwait tend to enjoy a good experience and decent salary. However, they may need upskilling in terms of the acquisition of the language needed in the receiving country. In addition, cultural adaptation and making adjustments to manage homesickness were among the strategies for surviving in the workplace whilst working in Kuwait.
\end{abstract}

Keywords: Indonesian nurses; Life experience; Nurses in Kuwait; phenomenology study

\section{Introduction}

Notwithstanding that nursing is the largest group of the health workforce, a shortage of nurses has become a global concern (Efendi et al., 2019; Russo et al., 2018). The World Health Organization (WHO) has estimated a global shortage of health workers, and in particular nurses and midwives - who represent more than $50 \%$ of the total workforce (WHO, 2020). The nursing supply is striving to meet the fast growing demand of health services due to the increasing population and aging society (Haddad et al., 2020; Nursalam et al., 2020), and it serves as a critical resource for achieving Universal Health Coverage (Russo et al., 2018). On the other hand, globalization has created a liberalized labor market which provides freedom for health workers, including nurses, to seek better working opportunities overseas (Aluttis et al., 2014; Nursalam et al., 2020).
As an international issue, cross-border nurse migration has a major impact on both the countries of origin and the destination country (Adhikari and Grigulis, 2014; Asongu, 2014; Benton et al., 2014; Lorenzo et al., 2007). International nurse migration aims to restore the disproportion of nursing personnel in the destination country with positive and negative consequences for the national health system of the country of origin (Buchan, 2006; Freeman et al., 2012; Khaliq et al., 2009; Lorenzo et al., 2007). By hiring foreign nurses, destination countries can reduce shortages of domestic nurses and help maintain national health systems (Aiken et al., 2004; Ross et al., 2005). The sending countries may enjoy economic benefits from the overseas remittance; however, the loss of competent health personnel adversely affects some countries who have more fragile health systems (Brush and Sochalski, 2007; Dimaya et al., 2012).

Recruitment of foreign nurses has been actively conducted by high income countries, such as the Middle Eastern coun-

\footnotetext{
* Corresponding author: Ferry Efendi, Universitas Airlangga, Faculty of Nursing, Kampus C Mulyorejo, Surabaya, 60115, East Java, Indonesia; e-mail: ferry-e@fkp.unair.ac.id http://doi.org/10.32725/kont.2020.040

Submitted: 2020-04-11 • Accepted: 2020-11-02 • Prepublished online: 2020-11-06 
tries, to support their health system (Alboliteeh et al., 2017). Some Middle Eastern countries have been reported to have a high dependency on foreign nurses, such as $97 \%$ in the United Arab Emirates and 76\% in Saudi Arabia (El-Haddad, 2006; Mitchell, 2009). Similarly, in Kuwait, domestic nurses comprise only $6.6 \%$ of the national nursing workforce (Al-Jarallah et al., 2009). Another possible reason may be the fact that women in the Gulf countries are not interested in choosing careers in nursing due to their beliefs (Oda et al., 2018).

Even though Indonesia is not a major exporter of a nursing workforce, this country has been recognized as an active player in the sending of nurses abroad (Kurniati and Efendi, 2013; Kurniati et al., 2017). Since early 2000, Indonesia has enacted health workforce migration policies related to the management of Indonesian nurses abroad to ensure equal opportunity and promote justice in the migration process (Efendi et al., 2017). As of 2018, there are 320,772 nurses practicing in Indonesia (MoH, 2019), given the fact that more than 361,238 newly graduated nurses entered the domestic labor market in the same year $(\mathrm{MoH}, 2019)$. Therefore, the international migration policy of the Indonesian health workforce was intended to focus more on the expansion of the nursing labor market to foreign countries (Efendi et al., 2017; 2018).

Four major destination countries of Indonesian migrant nurses are located in the Middle East region, including Saudi Arabia (26\%), Kuwait (18\%), United Arab Emirates (3\%), and Qatar (2\%) (MoH, 2018). The migration of Indonesian nurses to the Middle Eastern countries has been known as early as the 1990s. Although the exact number is difficult to determine, nearly one thousand Indonesian nurses have been working in Kuwait since early 2000 (MoH, 2018). The phenomenon of the mobility of Indonesian nurses to Kuwait has become an interesting point that needs further exploration. Previous literature has reported various pull and push factors that motivated nurses to work overseas, including social and economic conditions, working environment, and career advancement (Brush, 2008; Kingma, 2008; McGillis Hall et al., 2009). However, to date, there has been no research that explores the experience of Indonesian nurses living and working in Kuwait. Therefore, this study may reveal new insights from the point of view of such Indonesian nurses. The findings are expected to benefit both countries in maximizing the benefits of migration to both countries and to present lessons learned to other countries.

\section{Materials and methods}

This research uses a phenomenological qualitative approach. Phenomenology is chosen to provide researchers with an understanding of the phenomenon experienced through the viewpoint of the research subject (van Manen, 1997).

\section{Participants}

Participants in this study were Indonesian nurses working in Kuwait with a minimum of one-year working experience. Participants were recruited through the snowball sampling method. Prospective study participants were contacted by phone and Messenger. A total of 21 participants agreed to participate in this study. The interview schedule was set up upon the confirmation of the participant's agreement.

\section{Procedure}

The research data were collected through direct interviews (face-to-face) in Kuwait. The place of interview was agreed to by the participants, and conducted in a convenient location, mostly near the workplace of the participants. Prior to the interview, the prospective participants were given an explanation about the study, the voluntary nature of their participation, and the right to withdraw from the research at any time. All participants submitted written consent and agreed to participate. Participants were requested to fill in the questionnaire of sociodemographic data, which included aspects such as gender, age, marital status, number of children, place of origin in Indonesia, degree or educational qualification, area of professional work in Indonesia and in Kuwait, years of nursing career in Indonesia and in Kuwait, and the current salary in Kuwait.

Interviews were conducted using the semi-structured interview method. As interview guidance, researchers developed a set of questions that might reflect the motivation of nurses to select Kuwait as their migration destination, significant experiences related to their social and professional life in Kuwait, and their expectations for a better management of the international nurse migration. The interview included the following questions: 'Please can you tell me the reasons for you working as a nurse in Kuwait?', 'What are the experiences that you consider the most significant during your stay in Kuwait?', 'What situations in Kuwait forced you to adapt and deal with the challenges?', 'What particular experiences that you expected happened or did not happen to other migrant nurses?', 'How did your training as a nurse in your home country help you to perform the nursing practice in Kuwait?' 'Based on your own experience and views, what kind of particular preparations and support is required for international nurses before coming to work in Kuwait?'. The time duration allocated for this data collection was approximately 60 minutes for each respondent. Verbal data were collected through digital audio recording. The protection of the research subjects' privacy was enabled through a password. The research transcript data of each research subject were analyzed and reviewed jointly by the research team regarding the content, consistency, and conclusion aspects of the thematic description.

\section{Data analysis}

Data transcription of this study was carried out through a verbatim process involving two members of the research team. The results of the transcription were then analyzed using $\mathrm{NVi}$ vo $^{\circledR}$ software version 11 . This software is used as a tool to help researchers highlighting or selecting statements that seem significant to this study. The overall process of data analysis followed van Manen's approaches: (a) reading the interview transcripts several times to get an impression and understand the meaning; (b) selecting important phrases or statements by researchers individually; (c) extracting the texts to construct the concept which reflects the important themes; (d) conducting collaborative analysis sessions among researchers to verify any discrepancies and similarities of the constructed concept; (e) formulizing the preliminary themes and categories; and (f) reviewing and discussing the preliminary results until the ultimate structure of themes was agreed by all researchers. Trustworthiness in this study was evaluated using the hermeneutical cycle concept (Guba and Lincoln, 1989). The evaluation process included performing credibility, dependence, appropriateness, and applicability in research to improve the quality of research (Guba and Lincoln, 1989). To ensure credibility, participants were invited to check the preliminary result for consistency and feedback. Interview transcripts with highlighted statements and initial interpretation were sent by email to the participants to allow further clarification. Dependence was maintained through examining the analytical process 
done by researchers. The reserchers conducted a peer-review approach to validate the method used and analysis during the research process. Appropriateness was established through creating a diary to track the implemented procedures and the agreed concepts. The research diary served as a reflective journal to maintain the consistency between the data collection process and the research questions. Applicability was ensured by incorporating data that enables readers to assess the possible transformation of this finding in other settings. It will also enable other researchers to establish applicable reconstruction in different settings.

\section{Characteristics of the participants}

Of the 21 nurses who participated in this study, there were nine females and 12 males. Based on marital status, there were four married participants and 17 unmarried participants, with an age range of 31-45 years old. Most participants have the educational background of a Diploma of Nursing (76\%), while others hold a Bachelor's of Nursing (14\%) and Master's in Nursing (10\%). Most participants work in the emergency room (61\%), and others (39\%) in the operation room, longterm care, outpatient room, and inpatient room. Most participants have been living and working in Kuwait for 6-10 years (76\%) (Table 1). Estimated income per month in Indonesian Rupiahs (IDR) was 23,000,000 to 33,000,000 or 1769 to 2561 in US Dollars (USD).

\section{Table 1. The characteristics of the participants}

\begin{tabular}{lrr} 
Characteristic & $n$ & $\%$ \\
\hline Gender & & \\
$\quad$ Female & 9 & 43 \\
$\quad$ Male & 12 & 57 \\
\hline Marital status & & \\
$\quad$ Married & 4 & 19 \\
$\quad$ Unmarried & 17 & 81 \\
\hline Age (years) & $31-45$ & \\
\hline Education & & \\
$\quad$ Diploma in nursing & 16 & 76 \\
Bachelor's in nursing & 3 & 14 \\
$\quad$ Master's in nursing & 2 & 10 \\
\hline Workplace & & \\
$\quad$ Emergency room & 13 & 61 \\
Others (operation room, long-term care, & 8 & 39 \\
outpatient room, and inpatient room) & & \\
\hline Work experience & & \\
6-10 years & 16 & 76 \\
11-15 years & 1 & 5 \\
16-20 years & \\
> 20 years & 3 & 14 \\
\hline
\end{tabular}

The analysis generated five themes. The emerging themes illustrate the experience of Indonesian nurses becoming migrant workers as the focus of this study. These include: "Escalating career prospects"; "Immersing in the local culture"; "Added value for Muslims"; "Language barrier", and "Dealing with homesickness".

\section{Ethical approval}

This research has been declared ethically feasible by the Health Research Ethics Commission of the Faculty of Nursing, Universitas Airlangga, with the ethical approval number 441$\mathrm{KEPK} / 2017$. To protect the participants' identity, pseudonyms were used when presenting the research data.

\section{Results}

First theme: Escalating career prospects

Most nurses saw migrating to Kuwait to work as a nurse as a way to improve their welfare, especially the family income. Although economics was the major motive among nurses, others also mentioned their intention to gain more experience in nursing practice.

"I am here because of the classical reason: to improve my family income. I want a much higher salary than what I earned in Indonesia. More importantly, having overseas work experience also gives me a chance to develop and update my nursing skills. In my hospital, I have gone through a challenging experience with the use of various surgical equipment" (P11).

"As a nurse, I learn a lot in this hospital about how to perform interprofessional collaboration to provide the best care for our patients. Nurses can focus on their professional work because there is a clear job description and definite boundaries with other medical professionals" (P14).

It is interesting that most participants mentioned receiving the privilege of employment status as civil servants from the Government of Kuwait. For many Indonesian nurses, to be employed as a civil servant is one of the most rewarding statuses to have. Being a government employee means having a settled job and a clear career path.

"All nurses are recruited based on the government job order. Our employment is managed by the Government of Kuwait. I think it is good to have an opportunity to become a civil servant in a foreign country" (P5).

"If you start (your career) as a nurse assistant, and you show performance excellence at least twice within five years, then you can be promoted as a registered nurse. After five years, you may go a level up and become a Nurse One. If you hold a bachelor's degree in nursing, you can become a specialist" (P1).

Developing career prospects in Kuwait enabled Indonesian nurses to improve their skills, knowledge, and experiences in nursing. Most participants expected their home country to take advantage of this human capital to support the national development, as they have no desire to stay permanently in Kuwait. Some participants expected their return would contribute to the improved healthcare system in Indonesia, while others planned to open their own business.

"Living permanently in Kuwait is not my desire, it is just to gain experience. I want to do something to improve the welfare of nurses, maybe running my own business" (P16).

"I am thinking of opening a primary clinic to help the poor to have a good health service" (P9).

"I would go back to Indonesia and teach nursing. Then I can share my experience, knowledge and skills to other nurses or nursing students" (P15).

"I want to set up a business to share my positive experience as a nurse and motivate other Indonesian nurses to work abroad" (P14).

"Of course, I will return and be an entrepreneur" (P17).

Second theme: Immersing in the local culture

Some participants recalled their experience when they first arrived in this country. To participants, the local culture is a blend of Islam and Arabian. Therefore, despite being Muslims, participants still considered adapting and complying with the Kuwait culture - in both the workplace and their social life - as a crucial issue. The participants learned about the local norms; for instance dress and travel restrictions for women, and the nature of the people. 
"To get an understanding of nursing, I was encouraged to observe the specific habits which are uncommon or different to people's habits in Indonesia, in order to give patients proper treatment. One of the norms in this country is that women have limitations in what they can wear, and even in traveling to some places" (P9).

"I had to get myself used to saying 'assalamualaykum' (peace be with you) every time I encountered someone or my patients" (P11).

"Patience is an attitude that one must have. People here tend to speak in a high tone and sometimes give orders in unpleasant ways. Patients usually feel entitled for special treatment and are very impatient to get the service quickly" (P1).

"To understand the nature of local people, patience is the key, so you can handle the patient's anger" (P6).

"This is like entering someone's house. The first is manners. Then, you will earn respect from Kuwaitis if you can speak, read and write Arabic" (P18).

Third theme: Added value for Muslims

Some participants feel blessed and grateful for working in $\mathrm{Ku}-$ wait because it is a Muslim country and they don't, therefore, experience difficulty in terms of religious practice. Such views can be seen in the following interview excerpts:

"It is a relief to work in Kuwait. Because Kuwait is an Islamic country where I can connect with other Muslims, just like in Indonesia" (P1).

"Alhamdulillah (thank God). In Kuwait, we have the freedom to worship as a Muslim. I have no worries in relation to performing daily prayers during work time" (P10).

"As a Muslim country, Kuwait allows freedom in worship activities. We (as foreign Muslims) find no difficulties in worshipping or practicing our religious activities" (P17).

"Kuwait is a Muslim country and has similarities with Indonesia. There are slots/times for workers to worship. There is no restriction for it" (P21).

The participants also mentioned other privileges of foreign Muslims who work in Kuwait. There is a wider opportunity to join Hajj or Umrah, the Islamic pilgrimage to Mecca, Saudi Arabia. This is another spiritual impetus that encouraged them to migrate to Kuwait.

"For me, working in Kuwait is about preparing for a better future, not only in this present life, but also afterlife. Because you can earn a good income and God's reward at the same time. Performing Hajj or Umrah is the dream of any Muslim, isn't it? Saudi Arabia and Kuwait share a border, so there are more chances to go (Hajj or Umrah)" (P14).

\section{Fourth theme: Language barrier}

The main problem felt by all participants in this research was the language barrier. Some Indonesian nurses found communicating at the work place a challenge due to their lack of English proficiency. Moreover, due to living in an Arab country, having Arabic proficiency, not only English, is also required to help in adapting to life more easily. The interview quotes below show how the participants experienced communication problems due to the language barrier:

"At the beginning, it was really stressful. My English skills are poor and embarrassing. Other nurses would laugh at the way I spoke English, and also misunderstood me" (P1).

"Language preparation is a must to be proficient in both English and Arabic. I am still not very good at either, especially for daily conversation" (P10).

"The language used is different from our mother tongue. We need to get prepared with English and Arabic skills, otherwise we are having constant misunderstandings in communication" (P9).
"My knowledge and skills in nursing might not be different from other international nurses, but I have problems understanding English dialects from various nationals" (P14).

"Understanding the local language is important. When you receive verbal abuse from the patients and their families, then you can request advocacy from the hospital" (P12).

"The problem is understanding specific medical terms in English, I think nursing schools in Indonesia should practice English more" (P17).

Fifth theme: Dealing with homesickness

Living in another country means the participants have to deal with homesickness. Most participants mentioned how life is while being far from their loved ones. They must live separately from their families for a certain period of time, and might only be able to meet occasionally after a year or so. Participants said some adjustments need to be made in order to deal with this situation. Maintaining a close relationship with their family in the home country, increasing their mental strength, and engaging in social life are among the strategies mentioned by participants to deal with homesickness. This can be seen in the following interview excerpts:

"I miss my parents and family in Indonesia so much that I call them by phone very often. It helps me feel better" (P20).

"It is difficult for us to return home every year. So, we keep in touch with our families in Indonesia through phone-calls. It is the best solution for this predicament" (P19).

"Living in a foreign country requires a strong will and a mentality of steel. Just keep focusing on the goal, work hard, and always remember your God and your family" (P10).

"If you feel lonely and homesick, get support from your community. They are your family here" (P14).

"I usually go out and socialize with local people. Not only can I understand their characters better, but it also reduces my homesickness" (P17).

"My friends are nurses from various countries. Sometimes we hang out and have a social life beyond our workplace" (P15).

\section{Discussion}

The first theme found was escalating career prospects, which illustrated both economic and social motives. The underlying economic motives of participants migrating are based on the desire to earn a higher stipend and to increase their welfare, while the main factors encouraging nurses to work abroad are the family's economic condition and the low salary earned in the country of origin. This was in accordance with studies which mentioned economic considerations as the main driver in nurse migration (Dywili et al., 2013; Efendi et al., 2016; Nursalam et al., 2020). Social motives involved the privileged status - as Indonesian nurses were recruited and hired at facilities owned by the Government of Kuwait. Participants felt proud of being a civil servant and this could subsequently enhance their career path as registered nurses or specialist nurses. This feeling is relatable because Indonesians consider civil service to be highly competitive employment. For example, in 2019 , a total of 152,286 job vacancies in various government facilities throughout Indonesia attracted approximately 5 million applications. With a 31,765 civil servant quota, health is among the sectors with the highest job vacancies - and it attracted hundreds of thousands of applicants (Kompas, 2019).

This finding also aligns with a study which mentioned that a good working environment, societal respect and recogni- 
tion of nurses are anticipated as reasons why nurses decide to migrate, and that they hope for greater job security and less workload as well as autonomy (Dywili et al., 2013). The other reason was that, from the perspective of being workers in a different country, their improved skills and knowledge obtained from overseas work experience would support the sustainability of their nursing career. Nurses also value being different from those other nurses who only have work experiences at hospitals in the home country. Research has found that international nurses' experience facilitates them to learn new skills, especially clinical skills and assessment skills, teamwork, new perspectives, and increased awareness (Brannan, 2013). Furthermore, the study participants also mentioned their willingness to return to their homeland, bringing with them knowledge, skills and experiences to support the nursing profession and healthcare system as well as to build entrepreneurship. Previous studies have also described how migrant nurses returned to contribute to the national health service system or to set up businesses (Adzei and Sakyi, 2014; Brown and Connel, 2004; Kurniati et al., 2017) In this study, living and working overseas is considered temporary; although the period of stay is uncertain for many nurses. Migration has not been seen as the ultimate goal. Instead, it is a means to collect capital from the host country, which can then be used to promote the nursing profession and health service as well as the economic development of the home country.

The second theme is about immersing in the local culture. It cannot be denied that overseas nurses experience different cultures (Lin et al., 2018) and this gives rise to the possibility to be sensitive to or experience cultural shock (Brannan, 2013; Doki et al., 2018). In this study, participants revealed the importance of understanding and accepting the local culture in order to adapt their life to the host country. For female nurses, the culture they must adapt to is the prohibition of women travelling alone, and covering their entire body - including face and hands - when in public. Although performing Islamic customs such as greetings and prayers in daily life is quite common among Muslim communities in Indonesia, some participants mentioned that the rituals are performed more intensively in this country, whether in the workplace or other settings. Another cultural difference experienced by the participants in the host country is feeling that they are treated as inferior by patients and families - who usually show a lack of patience when ordering a certain service. From the interviews, most participants maintained that a sense of entitlement has now become a common characteristic of the local people - as they are accustomed to receiving special care and medical services from foreign nurses. Participants tried to tolerate the people's characters and to adapt by developing patience. Research reports that adapting to different ways of working is required for nurses working abroad (Taylor, 2005). This matter is a challenge for nurses, especially for those going abroad for the first time (Adamson, 2018). At the same time, it can be an insight for nurses to learn about other cultures (Edmonds, 2010; Jose, 2011). Despite the participants' responses, the hospital management should provide support for international nurses to deal with cultural differences. The hospital management also needs to educate patients and their families about the position and the task of nurses to avoid prejudice and to foster a therapeutic nurse-patient relationship.

According to the narrative of participants, the third theme which appeared in this study is the added value of working in Kuwait, which means the benefits gained by participants as a Muslim working in a Muslim country. The participants have the opportunity to perform their religious activities as a Mus- lim without any restrictions - in the same way as their home country. Furthermore, participants will also have opportunities to take religious pilgrimages to other Islamic sites around Kuwait. Going to Makkah and Madinah in Saudi Arabia to perform Hajj and Umrah is spiritual compensation that is highly valued by Muslim nurses. Hajj is compulsory for Muslims who are financially, physically and mentally capable of performing it at least once in a lifetime. This condition elicits a grateful feeling, indicating the satisfaction of the participants. Research about job satisfaction finds that the feeling of workers related to both internal and external factors influences how satisfied someone is with the job (Aziri, 2011).

The main problem felt by all participants in this study was the language barrier, as has been indicated in previous studies (Doki et al., 2018; Edmonds, 2010; Lin et al., 2018). The main language barrier experienced by participants was English (Doki et al., 2018; Edmonds, 2010; Lin et al., 2018). The ability to communicate in English is greatly required by nurses who work abroad (Taylor, 2005) for interacting with patients, when working together with nurses on shifts, and in interacting with all other health workers and staff in the hospital where they work (Brannan, 2013; Gashash, 2016; Liou and Cheng, 2001; Taylor, 2005). Other than English, poor Arabic skills (as the host language) also pose another challenge to the participants' adaptation. The Government of Indonesia has acknowledged this problem, as reported by the National Agency for the Placement and Protection of Indonesian Workers (BNP2TKI, 2017), Indonesian labor migrants, including nurses, typically have language problems due to poor foreign language skills, which are one of the main keys in effective nursing communication.

The participants noted that linguistic incompetence has become an occupational stressor due to the inability to engage in professional and social communication with confidence. As a consequence of the language barrier, miscommunication leads to frustration for both the Indonesian nurses and the patients or their families. This situation may create a divergent understanding and social disruption between the nurses and the patients that results in verbal harassment or other unpleasant behavior, which is then perceived by the Indonesian nurses as the nature of the local people. This finding is similar to a study in Germany that reported the language difference was the primary occupational burden that hampers the effective interprofessional collaboration and the successful relationship between nurses and patients (Schilgen et al., 2019). The study participants suggested that successful adaptation at the workplace and living in a foreign country meant having a good foreign language preparation. It usually takes six months to a year for the study participants to adapt and master the foreign language. As highlighted in a previous study, the most significant barrier to successfully gaining employment as well as integrating within a foreign country is language (Higginbottom, 2011).

The last theme in this study describes the participants' feeling of homesickness and the strategies to deal with this. Feeling homesick is a common issue experienced by migrants arriving in the host country. Living isolated from family in another country can cultivate the feeling of missing them and loneliness. Although migrant nurses have the option to take annual leave and visit their family in Indonesia once a year, the participants usually utilize advanced communication technology to solve this problem. Making phone calls and using other means of communication, including social media, is a much cheaper way to get in touch with families at home. Previous studies reported that the use of smartphones as a family life 
communication tool was associated with family wellbeing health, happiness, and harmony (Guo et al., 2019; Shen et al., 2017). Furthermore, maintaining family functions and effectively coping with family problems may support the survival of nurse migrants in other counties. To improve the psychological balance in dealing with homesickness, other participants mentioned building a strong mentality through focusing on the goal of working abroad, maintaining a spiritual life, and engaging in the social life with other expatriates and local people. These strategies are similar to the findings of a previous study that suggested making contact with other people, whether from their own expatriate communities or other countries, as well as with the local people is effective in sustaining the psychological balance of migrants (Hack-Polay, 2012).

\section{Conclusions}

Indonesian nurses who work in Kuwait enjoy the privileges and benefits of international migration in terms of gaining economic profits, a career as a professional nurse and civil servant, as well as the added value of their spiritual life as Muslims. However, the participants also noted some struggles related to understanding the local culture and practicing English and Arabic skills, especially at the workplace. Homesickness experienced by the participants was addressed through various coping strategies. Preparing Indonesian nurses with a tailored program on language and cultural issues is critical before their departure to work overseas. Support is needed to enhance the integration of Indonesian nurses in the Kuwaiti community. This integration is crucial to help to create easier adaptation for international nurses and to improve positive acceptance among other expatriate and local nurses as well as the patients and their families. In addition, the integration may also drive Indonesian nurses to consider a permanent career as a nurse in Kuwait. On the other hand, the willingness of Indonesian nurses to return home and continue their career as a nurse or entrepreneur should be welcomed by the Indonesian policy makers in order to optimize the nurses' positive contribution to the economic development. Future studies related to the quality of life and retention issue of Indonesian nurses in Kuwait should be considered with regard to the sustainability aspect.

\section{Conflicts of interests}

The authors have no conflict of interests to declare.

\title{
Prožité zkušenosti indonéských zdravotních sester v Kuvajtu: fenomenologická studie
}

\begin{abstract}
Souhrn
Úvod: Indonésie je uznávaným státem při vysílání zdravotnických pracovníků včetně zdravotních sester do zahraničí. Indonéské zdravotní sestry jsou umístěny také v zemích Středního východu, jako je Kuvajt. Přesto neexistuje mnoho výzkumů, které prověřují životní zkušenosti indonéských sester žijících a pracujících v Kuvajtu.

Metody: Jedná se o kvalitativní studii s fenomenologickým př́stupem. Tato studie obsahovala 21 indonéských zdravotních sester, které žily a pracovaly v Kuvajtu alespoň jeden rok. Respondenti byli přijati z nemocnic v Kuvajtu. Byla využita metoda polostrukturovaných rozhovorů, které byly provedeny na předem určených místech. Data byla poté doslovně přepsána a tematicky analyzována.

Výsledky: Bylo identifikováno pět témat: stupňování kariérních vyhlídek, ponoření do místní kultury, přidaná hodnota pro muslimy, jazyková bariéra a řešení stesku po domově.

Diskuse: Ekonomické a sociální motivy respondentů odrážely různé migrační cíle. Život v muslimské zemi mezitím snižuje stres a může sloužit jako výhoda během migrace.

Závěr: Indonéské zdravotní sestry, které pracují v Kuvajtu, mají obvykle dobré zkušenosti a slušný plat. Mohou však potřebovat zvyšování kvalifikace, pokud jde o osvojení jazyka potřebného v cílové zemi. Kulturní adaptace a řešení stesku po domově navíc patřily mezi strategie, jak práci v Kuvajtu zvládat.
\end{abstract}

Klíčová slova: fenomenologická studie; indonéské zdravotní sestry; zdravotní sestry v Kuvajtu; životní zkušenost

\section{References}

1. Adamson E (2018). Culture, courage and compassion: exploring the experience of student nurses on placement abroad. Journal of Compassionate Health Care 5(1): 1-9. DOI: 10.1186/s40639018-0048-4.

2. Adhikari R, Grigulis A (2014). Through the back door: nurse migration to the UK from Malawi and Nepal, a policy critique. Health Policy Plan 29(2): 237-245. DOI: 10.1093/heapol/ czt010.

3. Adzei AA, Sakyi EK (2014). Drivers of return migration of Ghanaian health professionals: perspectives from doctors and nurses in urban Ghana. Int J Migr Health Soc Care 10(2): 102-120. DOI: 10.1108/IJMHSC-06-2013-0014.

4. Aiken LH, Buchan J, Sochalski J, Nichols B, Powell M (2004). Trends in international nurse migration. Health Affairs 23(2): 69-77. DOI: 10.1377/hlthaff.23.3.69.
5. Al-Jarallah KF, Moussa MA., Hakeem SK, Al-Khanfar FK (2009). The nursing workforce in Kuwait to the year 2020. Int Nurs Rev 56(1): 65-72. DOI: 10.1111/j.1466-7657.2008.00654.x.

6. Alboliteeh M, Magarey J, Wiechula R (2017). The Profile of Saudi Nursing Workforce: A Cross-Sectional Study. Nurs Res Pract ID: 1710686. DOI: 10.1155/2017/1710686.

7. Aluttis C, Bishaw T, Frank MW (2014). The workforce for health in a globalized context - global shortages and international migration. Glob Health Action 2014: 7. DOI: 10.3402/gha. v7.23611.

8. Asongu SA (2014). The impact of health worker migration on development dynamics: Evidence of wealth effects from Africa. Eur J Health Econ 15(2): 187-201. DOI: 10.1007/s10198-0130465-4.

9. Aziri B (2011). Job Satisfaction: A Literature Review. Manag Res Pract 3(1): 77-95.

10. Benton DC, González-Jurado MA, Beneit-Montesinos JV (2014). Professional regulation, public protection and 
nurse migration. Collegian 21(1): 53-59. DOI: 10.1016/j. colegn.2013.01.001.

11. BNP2TKI (2017). Strategi Mempersiapkan Perawat Indonesia Standar International. [online] [cit. 2020-03-25]. Available at: https://www.scribd.com/presentation/336872210/ Rev-Strategi-Mempersiapkan-Perawat-Indonesia-StandarInternational

12. Brannan MD (2013). Gaining perspectives of international nursing experiences: a survey of registered nurses. Master's thesis, Faculty of Education, Queen's University, Kingston, Ontario, Canada.

13. Brown RPC, Connel J (2004). The migration of doctors and nurses from South Pacific Island Nations. Soc Sci Med 58(11): 2193-2210. DOI: 10.1016/j.socscimed.2003.08.020.

14. Brush BL (2008). Global nurse migration today. J Nurs Scholarsh 40(1): 20-25. DOI: 10.1111/j.15475069.2007.00201.x.

15. Brush BL, Sochalski J (2007). International Nurse Migration: Lessons From the Philippines. Policy Politics Nurs Pract 8(1): 37-46. DOI: 10.1177/1527154407301393.

16. Buchan J (2006). The Impact of Global Nursing Migration on Health Services Delivery. Policy Polit Nurs Pract 7(Suppl. 3): 16S-25S. DOI: 10.1177/1527154406291520.

17. Dimaya RM, McEwen MK, Curry LA, Bradley EH (2012). Managing health worker migration: a qualitative study of the Philippine response to nurse brain drain. Hum Resour Health 10: 47. DOI: 10.1186/1478-4491-10-47.

18. Doki S, Sasahara S, Matsuzaki I (2018). Stress of working abroad: a systematic review. Int Arch Occup Environ Health 91(7): 767-784. DOI: 10.1007/s00420-018-1333-4.

19. Dywili S, Bonner A, O’Brien L (2013). Why do nurses migrate? a review of recent literature. J Nurs Manag 21(3): 511-520. DOI: 10.1111/j.1365-2834.2011.01318.x.

20. Edmonds ML (2010). The lived experience of nursing students who study abroad: A qualitative inquiry. J Stud Int Educ 14(5): 545-568. DOI: 10.1177/1028315310375306.

21. Efendi F, Chen CM, Kurniati A, Nursalam N, Yusuf A (2018). The Situational Analysis of Nursing Education and Workforce In Indonesia. Malaysian J Nurs 9(4): 20-29.

22. Efendi F, Chen CM, Nursalam N, Indarwati R, Ulfiana $E$ (2016). Lived experience of Indonesian nurses in Japan: A phenomenological study. Jpn J Nurs Sci 13(2): 284-293. DOI: $10.1111 /$ jjns.12108.

23. Efendi F, Kurniati A, Bushy A, Gunawan J (2019). Concept analysis of nurse retention. Nurs Health Sci 21(4): 422-427. DOI: $10.1111 / \mathrm{nhs} .12629$.

24. Efendi F, Mackey TK, Huang M-C, Chen C-M (2017). IJEPA: Gray Area for Health Policy and International Nurse Migration. Nurs Ethics 24(3): 313-328. DOI: $10.1177 / 0969733015602052$.

25. El-Haddad M (2006). Nursing in the United Arab Emirates: An historical background. Int Nurs Rev 53(3): 284-289. DOI: 10.1111/j.1466-7657.2006.00497.x.

26. Freeman M, Baumann A, Fisher A, Blythe J, Akhtar-Danesh N (2012). Case study methodology in nurse migration research: An integrative review. Appl Nurs Res 25(3): 222-228. DOI: 10.1016/j.apnr.2012.02.001.

27. Gashash B (2016). Islamic values, cultural customs and influences upon delivery of Acute and Critical Care nursing services to patients admitted to Saudi Arabian hospitals. A thesis submitted in fulfillment of the requirements for the Degree of Doctor of Philosophy. Bandar.

28. Guba EG, Lincoln YS (1989). Fourth generation evaluation. Newbury Park, CA: Sage.

29. Guo N, Wang MP, Luk TT, Ho SY, Fong DYT, Chan SSC, Lam TH (2019). The association of problematic smartphone use with family well-being mediated by family communication in Chinese adults: A population-based study. J Behav Addict 8(3): 412-419. DOI: 10.1556/2006.8.2019.39.

30. Hack-Polay D (2012). When home isn't home: A study of homesickness and coping strategies among migrant workers and expatriates. International Journal of Psychological Studies, 4(3): 62-72. DOI: 10.5539/ijps.v4n3p62.
31. Haddad LM, Annamaraju P, Toney-Butler TJ (2020). Nursing Shortage. Treasure Island (FL): StatPearls Publishing.

32. Higginbottom GMA (2011). The transitioning experiences of internationally-educated nurses into a Canadian health care system: A focused ethnography. BMC Nursing 10(1): 14 DOI: 10.1186/1472-6955-10-14.

33. Jose MM (2011). Lived experiences of internationally educated nurses in hospitals in the United States of America. Int Nurs Rev 58(1): 123-129. DOI: 10.1111/j.1466-7657.2010.00838.x.

34. Khaliq AA, Broyles RW, Mwachofi AK (2009). Global nurse migration: its impact on developing countries and prospects for the future. World Health Popul 10(3): 55-73.

35. Kingma M (2008). Nurse migration and the global health care economy. Policy Polit Nurs Pract 9(4): 328-333. DOI: $10.1177 / 1527154408327920$.

36. Kompas (2019). Update CPNS 2019: Link Cek Jumlah Pelamar Setiap Formasi, Jadwal Terbaru dari BKN. [online] [cit. 2020-07-12]. Available from: https://www.kompas.com/tren/ $\mathrm{read} / 2019 / 12 / 12 / 064300465 /$ update-cpns-2019--link-cekjumlah-pelamar-setiap-formasi-jadwal-terbaru?page=all

37. Kurniati A, Efendi F (2013). Human Resources for Health Country Profile of Indonesia. New Delhi: World Health Organisation.

38. Kurniati A, Chen C-M, Efendi F, Ogawa R (2017). A deskilling and challenging journey: the lived experience of Indonesian nurse returnees. Int Nurs Rev 64(4): 494-501. DOI: 10.1111/ inr.12352.

39. Lin Y-Q, Ding Y, Li J-Y (2018). A literature review of research exploring the experiences of overseas nurses in the United Kingdom (2002-2017). Frontiers of Nursing 5(1): 17-30. DOI: $10.1515 /$ fon-2018-0003.

40. Liou S-R, Cheng C-Y (2001). Experiences of a Taiwanese Nurse in the United States. Nursing Forum 46(2): 102-109. DOI: 10.1111/j.1744-6198.2011.00211.x

41. Lorenzo FME, Galvez-Tan J, Icamina K, Javier L (2007). Nurse migration from a source country perspective: Philippine country case study. Health Serv Res 42(3 Pt 2): 1406-1418. DOI: 10.1111/j.1475-6773.2007.00716.x.

42. McGillis Hall L, Pink GH, Jones CB, Leatt P, Gates M, Peterson J (2009). Is the grass any greener? Canada to United States of America nurse migration. Int Nurs Rev 56(2): 198-205. DOI: 10.1111/j.1466-7657.2008.00706.x.

43. Mitchell JE (2009). Job satisfaction and burnout among foreign-trained nurses in Saudi Arabia: A mixed-method study. Doctoral Dissertation, University of Phoenix, USA.

44. MoH (2018). Buku Saku Data Penempatan Tenaga Kerja Kesehatan Indonesia Ke Luar Negeri [Handbook of the Placement of Indonesian Health Workforce Overseas]. Jakarta: $\mathrm{MoH}$. [online] [cit. 2020-06-12]. Available from: http:// siskotkln.bnp2tki.go.id/files/Juknis_update_medical.pdf

45. $\mathrm{MoH}$ (2019). Human Resources for Health Country Profiles: Indonesia. Jakarta: Kemenkes. [online] [cit. 2020-06-19]. Available from: https://www.kemkes.go.id/resources/download/ pusdatin/profil-kesehatan-indonesia/indonesia-healthprofile-2018.pdf

46. Nursalam N, Chen C-M, Efendi F, Has EMM, Hidayati L, Hadisuyatmana S (2020). The Lived Experiences of Indonesian Nurses Who Worked as Care Workers in Taiwan. J Nurs Res 28(2): e78. DOI: 10.1097/jnr.0000000000000355.

47. Oda H, Tsujita Y, Rajan SI (2018). An Analysis of Factors Influencing the International Migration of Indian Nurses. J Int Migr Integr 19: 607-624. DOI: 10.1007/s12134-018-0548-2.

48. Ross SJ, Polsky D, Sochalski J (2005). Nursing shortages and international nurse migration. Int Nurs Rev 52(4): 253-262. DOI: 10.1111/j.1466-7657.2005.00430.x.

49. Russo G, Fronteira I, Jesus TS, Buchan J (2018). Understanding nurses' dual practice: A scoping review of what we know and what we still need to ask on nurses holding multiple jobs. Hum Resour Health 16(1): 14. DOI: 10.1186/s12960-018-0276-x.

50. Schilgen B, Handtke O, Nienhaus A, Mösko M (2019). Workrelated barriers and resources of migrant and autochthonous homecare nurses in Germany: A qualitative comparative study. Appl Nurs Res 46: 57-66. DOI: 10.1016/j.apnr.2019.02.008. 
51. Shen C, Wang MP, Chu JT, Wan A, Viswanath K, Chan SSC, Lam TH (2017). Sharing Family Life Information Through Video Calls and Other Information and Communication Technologies and the Association With Family Well-Being: PopulationBased Survey. JMIR Ment Health 4(4): e57. DOI: 10.2196/ mental.8139.

52. Taylor B (2005). The experiences of overseas nurses working in the NHS: results of a qualitative study. Divers Equal Health Care 2: 17-27.
53. van Manen M (1997). From meaning to method. Qual Health Res 7(3): 345-369. DOI: 10.1177/104973239700700303.

54. WHO (2020). Health Workforce: Nursing and midwifery. [online] [cit. 2020-06-09]. Available from: https://www.who. int/hrh/nursing_midwifery/en/ 